DOI: $10.17951 /$ rh.2018.46.115-139

\author{
Wojciech Lorek \\ (Uniwersytet im. Adama Mickiewicza w Poznaniu) \\ https://orcid.org/0000-0002-1642-6706
}

\title{
Strategia i taktyka Henryka II podczas obrony Normandii w latach 1173-1174
}

\author{
The Strategy and Tactics of Henry II During the Defence of Normandy \\ in 1173-1174
}

\section{STRESZCZENIE}

W 1173 r., w wyniku niebezpiecznej sytuacji militarnej, król Anglii Henryk II Plantagenet stanął przed trudnym strategicznie zadaniem walki na kilku frontach i obrony przed spodziewanymi wrogimi działaniami w północnej i środkowej Anglii oraz w Normandii. Przeciwko władcy zbuntowali się jego synowie: Henryk zwany „Młodym Królem”, Ryszard oraz Gotfryd, wsparci przez silną koalicję pod przywództwem króla Francji Ludwika VII. To właśnie opanowanie księstwa Normandii i jego serca - Rouen, było głównym celem koalicjantów, na który skierowano ataki na południu, północnym wschodzie i zachodzie prowincji. Dla Henryka II obrona ziem normandzkich - ważnego strategicznie, politycznie i ekonomicznie terytorium - była kluczowa podczas zmagań wojennych. Celem niniejszego artykułu jest zbadanie strategii i taktyki Henryka II podczas obrony Normandii w latach 1173-1174, która była nowatorską odpowiedzią na działania jego wrogów. Istotnym zadaniem będzie również wykazanie walorów sztuki wojennej zastosowanej przez „Starego Króla”, które pozwoliły mu nie tylko na odparcie wrogich ataków na granicę normandzka, ale też umożliwiły zwycięstwo w całej wojnie.

Słowa kluczowe: strategia i taktyka, Plantageneci, imperium andegaweńskie, Wielka Rewolta 1173-1174, Normandia, Henryk II Plantagenet, wojskowość średniowieczna

Przetrwanie tzw. imperium andegaweńskiego ${ }^{1}$ - utworzonego przez Henryka II Plantageneta ogromnego władztwa obejmującego tereny od

1 Używam terminu wprowadzonego do historiografii jako umowne określenie ziem pod władaniem rodu Plantagenetów za panowania Henryka II, Ryszarda I Lwie Serce i Jana bez Ziemi. Pojęcie „Imperium Andegaweńskiego" stworzyła angielska mediewistka Kate Norgate pod koniec XIX w. w swej pracy pt. England under the Angevin Kings. 
granicy ze Szkocją przez Irlandię Południową i posiadłości we Francji od Normandii po Pireneje - w dużej mierze zależało od strategii obrony królestwa. Sprawna machina wojenna - nowoczesna i dobrze dowodzona armia oraz sieć królewskich fortec były w stanie skutecznie przeciwdziałać zarówno atakom z zewnątrz, ze strony agresywnych sąsiadów, jak i tłumić rebelie możnowładców, częstokroć niezadowolonych z potężnej pozycji monarchy i nakładanych na nich licznych świadczeń fiskalnych, prawnych oraz militarnych. Dla Henryka II prawdziwym sprawdzianem strategii obronnej był bunt jego synów, wspieranych nie tylko przez część lokalnych baronów z Akwitanii, Poitou, Normandii, Bretanii i centralnej Anglii, ale przede wszystkim przez silną koalicję króla Szkocji Wilhelma I Lwa, hrabiego Flandrii Filipa Alzackiego i jego brata Mateusza z Boulogne oraz przez przywódcę sojuszu, króla Francji Ludwika VII Młodego.

W wyniku niebezpiecznej sytuacji militarnej król Anglii stanął przed trudnym strategicznie zadaniem walki na kilku frontach i obrony przed spodziewanymi wrogimi działaniami w północnej i środkowej Anglii oraz w Normandii. Dla Henryka II obrona ziem normandzkich, ważnego strategicznie, politycznie i ekonomicznie terytorium, była kluczowa podczas nadchodzących zmagań wojennych. To właśnie opanowanie księstwa i jego serca, Rouen, było głównym celem koalicjantów, na który skierowano główne ataki.

W niniejszym artykule postawiono sobie za zadanie zbadanie strategii i taktyki Henryka II podczas obrony Normandii w latach 1173-1174 i wykazanie istotnych walorów sztuki wojennej zastosowanej przez „Starego Króla", które pozwoliły mu nie tylko na odparcie wrogich ataków na granicę normandzka, ale też umożliwiły zwycięstwo w całej wojnie.

Rewoltę lat 1173-1174 i inwazję króla Francji oraz sprzymierzeńców na Normandię szczegółowo opisują źródła narracyjne - głównie kroniki autorów z kręgu anglo-normańskiego, stąd istnieje obawa, że na ogół przychylni Plantagenetom dziejopisarze, tacy jak Roger z Hoveden²,

Termin ten, choć często używany zarówno przez francuskich, jak i angielskich historyków, do dziś wzbudza kontrowersje. Por. K. Norgate, England under the Angevin Kings, 2 vols, London 1887; J. Gillingham, The Angevin Empire, second edition, London-New York 2001, s. 5; M. Aurell, L'Empire des Plantagenêt 1154-1224, Paris 2003, s. 5-14. Dla części badaczy określenie to nie jest jednak adekwatne, gdyż poza osobą silnego i zdolnego Henryka II poszczególnych terytoriów różniących się obyczajami i prawem nic nie łączyło. Stąd nie jest to imperium, w nowożytnym znaczeniu, zwartych terytoriów.

2 Roger of Hoveden, The Annals of Roger de Hoveden, 2 vols, tłum. H.T. Riley, LondonBohn 1853. 
Wilhelm z Newburgha ${ }^{3}$ czy Ralf z Diceto ${ }^{4}$, przedstawią działania wojenne nieobiektywnie, ukazując Henryka II w korzystniejszym świetle. Jednak pomijając słowa krytyki skierowane na zdrajców, opisy kampanii zasadniczo powtarzają się i zawierają wiarygodne fakty. Część informacji, podobnych do relacji wymienionych autorów, podaje rymowana Kronika wojny pomiędzy Anglikami a Szkotami w latach 1173-1174 autorstwa normańskiego kronikarza i truwera Jordana Fantosme' $\mathrm{a}^{5}$, choć autor skupia swoją relację głównie na zmaganiach sił rojalistów ze Szkotami. Niestety, kronikarze francuscy epoki nie dostarczają zbyt wielu informacji na temat przegranego przez ich króla konfliktu.

Literatura historyczna, anglosaska i francuska, poświęciła konfliktowi kilka prac, w dużej mierze skupiając się raczej na przyczynach, przebiegu i skutkach politycznych niż na wnikliwej analizie militarnej wojny. Podrozdział ukazujący ogólny przebieg rewolty dynastycznej umieścił w swej klasycznej biografii Henry II Wilfred Lewis Warren', a w najnowszej pracy o Henryku „Młodym Królu” Matthew Strickland ${ }^{7}$ w dwóch rozdziałach opisuje przyczynę konfliktu i kampanie, częściowo skupiając się również na obronie Normandii. Jak dotąd, jedyną monografią poświęconą rewolcie synów Henryka II jest War of the Generations: The Revolt of 1173-4, Thomasa Martina Jonesa'. Z kolei John Beeler w klasycznej pracy wojskowej Warfare in England 10661189 kampanię w Normandii całkowicie pomija, skupiając się wyłącznie na działaniach rebeliantów, rojalistów i Szkotów na terenie Anglii. Zasadniczo tylko John Hosler wnikliwie analizuje taktykę i strategię wojny 1173-1174 w swej publikacji Henry II: A Medieval Soldier at War ${ }^{9}$, porównując m.in. ataki koalicjantów w Anglii i w Normandii, a także badając taktykę Henryka II oraz rojalistów. Oprócz wymienionych prac, kilka innych dysertacji poświęconych wybranym zagadnieniom militarno-politycznym Plantagenetów poświęca nieco uwagi działaniom wojennym w latach 1173-1174, jednak bardziej jako tło innych rozważań niż studium militarne konfliktu ${ }^{10}$.

Przyczyny wybuchu buntu synów Henryka II są powszechnie znane. 24 maja 1170 r. w Opactwie Westminsterskim koronowano na kró-

3 William of Newburgh, The History of English Affairs, w: The Church Historians of England, t. 4, cz. 2, tłum. J. Stevenson, London 1861. Słownictwo poprawione w 1999 r. przez S. McLetchie.

4 Ralph de Diceto, Ymagines Historianum, w: The Historical Works of Master Ralph of Diceto, Dean of London, ed. W. Stubbs, London 1876.

5 Jordan Fantosme, Chronicle of the War between the English and the Scots in 1173 and 1174, tłum. wstęp i red. F. Michel, Londyn-Edynburg 1840.

6 W.L. Warren, Henry II, London 2000, s. 108-136.

7 M.J. Strickland, Henry the Young King, 1155-1183, New Heaven-London 2016.

8 T.M. Jones, War of the Generations: The Revolt of 1173-4, Ann Arbor 1980.

9 J.D. Hosler, Henry II. A Medieval Soldier at War, Leiden-Boston 2007.

10 Zob. bibliografia. 
la najstarszego syna Henryka II, również Henryka, zwanego „Młodym Królem" (czasem też Henrykiem III). Starszy Plantagenet chciał tym sposobem legitymować sukcesję dynastyczną dla swojego syna. Chociaż Henryk Młody otrzymał koronę, tytuł księcia Normandii, hrabiego Maine i Andegawenii oraz posiadał własny dwór, doradców i kancelarię, to faktyczna władza należała wyłącznie do jego ojca. Nic w tym dziwnego, bowiem jego najstarszy syn nie przedstawiał zadatków na dobrego władcę. Był ambitny, próżny i pyszny, a prawie cały majątek trwonił na wystawne życie pełne przepychu i turnieje rycerskie, których był zagorzałym fanem i sponsorem. Ponadto odznaczał się porywczością i brakiem rozwagi oraz łatwo ulegał wpływom. Tę słabość zręcznie wykorzystywał teść Henryka Młodego, król Francji Ludwik VII, który podsycał jego ambicje zdobycia samodzielnej władzy w całej Anglii ${ }^{11}$.

Pozostali synowie Godfryd i Ryszard również byli niezadowoleni z kurateli ojca nad teoretycznie należącymi do nich ziemiami. Piętnastoletni Ryszard - ulubieniec matki, Eleonory Akwitańskiej, w 1172 r. dzięki jej staraniom został koronowany na diuka Akwitanii. Z tego tytułu zarządzał również ziemiami w Poitou. Godfryd, zaręczony w 1161 r. z córką księcia Bretanii Konana IV, rościł sobie prawo do obiecanego księstwa bretońskiego. Jednak ani Henryk Młody, ani Ryszard i Godfryd nie zarządzali faktycznie swoimi domenami i nie mogli czerpać z nich dochodów, które płynęły do skarbca królewskiego.

Kolejną przyczyną było wzrastające niezadowolenie wśród części możnych w rozległych ziemiach władztwa Plantagenetów, spowodowane świadczeniami nałożonymi na feudałów, podatkami oraz ograniczeniami w prawach (m.in. przejmowanie kluczowych zamków i burzenie warownych siedzib wzniesionych bez zgody króla). Południowa granica Normandii - w szczególności zaś strategiczny rejon Vexin ${ }^{12}$ - stała się przedmiotem rywalizacji pomiędzy Ludwikiem VII a Henrykiem II, w którą siłą rzeczy włączeni byli feudałowie posiadający przygraniczne ziemie oraz panowie niezadowoleni z utraty swoich zamków na rzecz Plantageneta i silnej militaryzacji regionu ${ }^{13}$. Panowie często posiadali

11 T.M. Jones, War of the Generations: The Revolt of 1173-4, Ann Arbor 1980, s. 96; M.J. Strickland, Henry the Young King, 1155-1183, New Heaven-London 2016, s. 120.

12 W 1160 r. Henryk uzyskał Vexin francuski poprzez małżeństwo swojego najstarszego syna z Małgorzata, córką Ludwika VII, która wniosła te tereny jako wiano. Przygraniczne zamki, zwłaszcza Gisors, miały kluczowe znaczenie strategiczne, toteż zostały niezwłocznie wzmocnione przez króla. M.J Strickland, op. cit., s. 30-31.

13 D. Power, The Norman Frontier in the Twelth and Early Thirteenth Centuries, Cambridge 2008, s. 397; M. Aurell, Révolte nobiliaire et lutte dynastique dans l'Empire angevin (1154-1224), w: Anglo-Norman Studies XXIV, Proceedings of the Battle Conference, Woodbridge 2001, s. 27. 
ziemie po obu stronach granicy, przez co podczas wojny przechodzili na stronę jednego z monarchów, w zależności od własnych interesów. Normandia w latach poprzedzających Wielką Rewoltę, w 1161 r. i w latach 1167-1168, stała się areną zaciekłych walk granicznych i najazdu francuskiego. W 1167 r., gdy Henryk II zajęty był atakiem na Perche i łupieniem Chaumont-en-Vexin, armia króla Francji wdarła się do Normandii, paląc Les Andelys i Gasny, a sprzymierzeni z Ludwikiem VII hrabiowie Flandrii i Boulogne oblegali Drincourt na północnym zachodzie regionu, pustosząc okoliczne ziemie ${ }^{14}$. To oraz niemożność przeciwdziałania atakom jednocześnie od strony Flandrii i Vexin z pewnością dała sporo do myślenia Henrykowi, który umocnił okoliczne twierdze i nie dopuścił do powtórzenia sytuacji w $1173 \mathrm{r}$. Wspomniane najazdy francusko-flandryjskie nękające przygraniczne tereny z pewnością rujnowały majątki okolicznych feudałów, pogarszając ich sytuację ekonomiczną.

Ważną kartą wrogów Plantagenetów w grze propagandowej przeciw Henrykowi II była wciąż ostatecznie nierozwiązana sprawa zabójstwa arcybiskupa Canterbury Tomasza Becketa, zasieczonego mieczami trzech rycerzy w służbie Henryka II w katedrze w Canterbury 29 grudnia 1170 r. Chociaż nie było jednoznacznych dowodów, że to właśnie król wydał rozkaz zamordowania sługi Kościoła i Henrykowi II udało się całą sprawę nieco załagodzić poprzez porozumienie z Kościołem, sprawa Tomasza Becketa została ponownie podjęta przez spiskowców dążących do obalenia potęgi Henryka $\mathrm{II}^{15}$.

Iskra, która wznieciła płomień konfliktu, stało się przyznanie trzech kluczowych fortec najmłodszemu synowi królewskiemu Janowi, któremu nie przekazano do tej pory żadnych majątków, stąd też pojawił się jego przydomek - bez Ziemi. Stało się to podczas zjazdu w Limoges 25 lutego 1173 r., kiedy to Henryk II negocjował warunki zaręczyn swego pięcioletniego syna z córką Humberta, hrabiego Maurienne. Zatroskany o los swej dziedziczki Humbert spytał monarchę, jakie ziemie przekaże jej przyszłemu mężowi, na co Plantagenet odparł, że przekaże mu zamki w Chinon, Mirabeau i Loudun ${ }^{16}$. Decyzja ojca rozwścieczyła Henryka Młodego, który nie zgodził się, jako koronowany król, na takie rozporządzanie jego zie-

14 D. Power, op. cit., s. 398.

$15 \mathrm{Na}$ temat sprawy Tomasza Becketa i ugody z papieżem w Avranches zob.: W.L. Warren, op. cit., s. 108-114.

16 Gesta Regis Henrici Secundi - The Chronicle of Henry II and Richard I AD 1169-1192, ed. W. Stubbs, London 1867, s. 41. John Gillingham uważa, że przekazanie kluczowych fortec najmłodszemu dziecku było celowym wybiegiem Henryka, gdyż dzięki temu monarcha mógł nimi zarządzać przez wiele lat. J. Gillingham, Ryszard Lwie Serce, tłum. N. Rataj, M. Józefowicz, Kraków 2017. 
miami i zażądał od króla części swojego dziedzictwa, możliwości wyłącznego zarządzania tymi ziemiami oraz czerpania dochodów w Andegawenii, Normandii lub w Anglii. Podobnie kolejni synowie Godfryd i Ryszard surowo protestowali, żądając samodzielnego władania kolejno w Bretanii i Normandii. Ambicje królewskich synów podsycała Eleonora Akwitańska, niechętna wobec męża z powodu odsunięcia od spraw politycznych oraz być może jego romansu ${ }^{17}$. Choć Henryk II miał nadzieję, że załagodzi spór z najstarszym synem, aranżując spotkanie w Chinon, to na wszelki wypadek zamknął go pod strażą. Jednak mimo to Henrykowi Młodemu udało się zbiec z zamku pod osłoną nocy i dołączyć do swoich braci, którzy dotarli wcześniej do Paryża na dwór głównego architekta spisku - Ludwika VII.

"Zatem szaleństwo jednego, pociągnęło wiele szaleństw"18 - komentuje w swej kronice Roger z Hoveden. Rzeczywiście wydarzenia potoczyły się lawinowo, gdyż dla wielu pojawiła się dogodna okazja do wyrównania dawnych zatargów oraz zdobycia korzyści finansowych, politycznych i terytorialnych. Z konfliktu dynastycznego Plantagenetów najbardziej zadowolony był król Francji, gdyż wreszcie nadarzyła się dogodna okazja do zachwiania potęgi rywala. 8 kwietnia 1173 r. Ludwik VII zwołał do Paryża radę baronów i wasali w celu debatowania nad planem wojny z Henrykiem II. Tymczasem Henryk Młody, Ryszard i Godfryd złożyli przysięgę, że bez zgody króla i baronów Francji nie zawrą pokoju ze swoim ojcem i będą dążyć do zmuszenia go do abdykacji. Ludwik VII zręcznie poszerzył grono sojuszników o hrabiego Flandrii, Filipa Alzackiego, jego brata Mateusza z Boulogne, Tybalda z Blois oraz króla Szkocji Wilhelma Lwa. Koalicjantów zachęciła do włączenia się w konflikt nie tylko osobista niechęć do "Starego Króla”, ale przede wszystkim obiecane przez Henryka Młodego hojne nadania, po tym jak zdobędzie tron. W zamian za pomoc i hołd lenny hrabia Flandrii miał otrzymać 1000 funtów w srebrze rocznego dochodu w Anglii, wraz z hrabstwem Kentu i zamkami w Dover i Rochester, hrabia Boulogne - majątki Kirkekton w Lindsay i hrabstwo Mortaine, natomiast hrabiemu Blois obiecano 200 funtów w srebrze rocznego dochodu w Andegawenii, a także zamek Amboise wraz z przyległościami w Turenii. Kuszącą obietnicę otrzymał również król Szkocji, gdyż miano mu przyznać cały graniczny region Northumberland aż do rzeki Tyne, a królewskiemu bratu tytuł i majątek

17 Więcej na temat przyczyn zdrady Eleonory: W.L. Warren, op. cit., s. 119-121 i J. Gillingham, Ryszard Lwie Serce, s. 64-65.

18 Roger of Hoveden, op. cit., s. 363. 
earla Huntington oraz Cambridgeshire ${ }^{19}$. Reszta rebeliantów - wasali królewskich, którzy przyłączyli się do koalicji „Młodego Króla”, miała również otrzymać wartościowe ziemie i przywileje. Akty przyszłych nadań uwierzytelniono specjalnie sporządzoną nową "królewską" pieczęcią. Lekkomyślnemu i ambitnemu Henrykowi Młodemu łatwo przychodziło „,dzielenie skóry na żywym niedźwiedziu”, a dużo trudniej realizacja planów. Na razie jednak zbierano potężne siły, zaopatrzenie i planowano inwazję. Najeźdźcy mogli liczyć na poparcie części lokalnych baronów, którzy podnieśli bunt przeciw Henrykowi II. Kronikarze zgodnie informują że większość możnych zdradziła króla i przeszła do obozu wroga, nawet najbliżsi przyjaciele. Lista podawanych w źródłach rozpoznanych dezerterów nie jest jednak tak liczna, jak opisywali ówcześni dziejopisarze $^{20}$. Wśród spiskowców można wymienić m.in. Roberta, earla Leicester, zaciekłego wroga króla, posiadającego dobra w Anglii i na terenie Normandii oraz Ralfa de Fougères, przywódcę spiskowców bretońskich. Normandzcy feudałowie w większości pozostali wierni Henrykowi II, choć kilku pogranicznych feudałów czy to ze strachu, czy z chęci zysku dołączyło do koalicjantów. Ich głównym zamiarem miało być osłabienie i obalenie „Starego Króla” przez zdobycie kluczowej Normandii - regionu o sporych dochodach, niemal dorównujących wpływom z Anglii. Ponadto M.J. Strickland wskazuje, że zdobycie księstwa przecięłoby władztwo Plantagenetów na pół, utrudniając transport zapasów i wojsk do pozostałych kontynentalnych posiadłości ${ }^{21}$.

Granica Normandii nie była w większości wyznaczona przez przeszkody naturalne, z wyjątkiem odcinka na północnym wschodzie przez rzeki Bresle i Eure na linii od Aumale do Eu, gdzie rzeka Epte oddziela Vexin normandzki od francuskiego, oraz graniczne tereny nad rzeką Avre przepływającą przez bory Perche. Choć płynące z południa i wpadające do morza rzeki - np. meandrująca Sekwana - nie były naturalną przeszkodą na granicy, to gwarantowały komunikację wodną pomiędzy miastami w centrum a portami na wybrzeżu, takimi jak Dieppe czy najważniejszy Barfleur, gdzie stacjonowała królewska flota, umożliwiająca przesył zapasów, wojsk oraz informacji między Anglią a kontynentalnymi terytoriami Andegawenów ${ }^{22}$. Dwadzieścia pięć okrętów obsadzonych przez doświadczonych i dobrze opłacanych marynarzy pozwalało Henrykowi wypłynąć

\footnotetext{
19 Ibidem, s. 363.

${ }^{20}$ Lista antyrojalistów w: K. Norgate, op. cit., s. 136.

21 M.J. Strickland, op. cit., s. 151-152.

${ }^{22}$ J.D. Hosler, The Warfare of Henry II, 1149-1189, praca doktorska, Ann Arbor 2005, s. $117-118$.
} 
w morze w każdych niemal warunkach ${ }^{23}$. Teren księstwa pofałdowany był wzgórzami i dolinami oraz nierzadko stromymi i wysokimi skalistymi graniami, na których wzniesiono zamki i ufortyfikowane miasta, górujące nad okolicą oraz broniące biegnących w głąb regionu traktów. Kolejni diukowie Normandii dokładali wszelkich starań, by umacniać granice księstwa i trzymać w ryzach przygranicznych feudałów, skorych do buntów oraz zmiany stron konfliktu. Henryk II, wzorem swoich poprzedników, Wilhelma Zdobywcy i Henryka I, korzystając z prawa, konfiskował prywatne zamki i rozbudowywał je, obsadzając królewskimi załogami ${ }^{24}$. Nie wydaje się, żeby wzniósł w regionie zbyt wiele fortec, lecz raczej umacniał i rozbudowywał już istniejące twierdze. Sieć umocnień i twierdz nie była dziełem przypadku, tylko starannie obmyślaną strategią obronną. Henryk II przed inwazją ,ulepszył lub odnowił niemal połowę wszystkich swoich zamków, a zwłaszcza Gisors, położonego na granicy normandzkiej"25. Dwie nieregularne linie fortec, obsadzone przez sierżantów oraz rycerzy, dowodzone przez lojalnych królewskich urzędników, miały za zadanie wytrzymać inwazję i wiązać wrogie siły niczym falochron, szachując przy tym okolicę. Pierścień zamków był wzmocniony od środka twierdzami w Falaise, Domfront i Montfort. Ponadto, by wzmocnić newralgiczny, słabo chroniony odcinek na równinach południowej granicy między Verneuil a Moulins nad rzeką Avre, król rozkazał w 1169 r. wykopać długi rów i wały ziemne, zapewne do obsadzenia przez okoliczne garnizony ${ }^{26}$. Garnizony królewskie mogły liczyć na wsparcie oddziałów najemnych, a także na transport zaopatrzenia $z$ wewnętrznych, ufortyfikowanych miast i ośrodków władzy w Rouen, Caen i Argentan. Normandzkie twierdze miały za zadanie wytrzymać do czasu zmobilizowania przez króla wojsk i przybycia armii królewskiej z Anglii. Co ważne, król mógł liczyć na zaplecze i bazy dla wojsk w miastach, gdyż te, wiążąc swoje interesy z monarchą, pozostały lojalne wobec Henryka II. Z silnymi twierdzami, które objechał i rozkazał wzmocnić dodatkowymi zbrojnymi i zapasami oraz zasobnym zapleczem, król Anglii postanowił poczekać na posunięcia nieprzyjacielskiej koalicji.

Plan kampanii, najprawdopodobniej autorstwa Ludwika VII, zakładał uderzenie jednocześnie $\mathrm{w}$ kilku miejscach na granicy normandzkiej

23 T.M. Jones, The Generation Gap of 1173-74: The War between the Two Henrys, "Albion" 1973, 5, s. 35.

24 M. Powicke, Utrata Normandii 1189-1204. Studia nad Historia Imperium Andegaweńskiego, tłum. I. Smoczyk-Jackowiak, Oświęcim 2016, s. 184.

${ }_{25}$ Actes de Henri II, nr 486, w: M. Powicke, op. cit., s. 189.

26 Robert de Torigny, The Chronicle of Robert of Torigny, w: Chronicles of Reigns of Stephen. Henry II and Richard I, t. 2, ed. R. Howlett, 13 Rolls Series, London-Oxford-CambridgeEdinburgh-Dublin 1884-1889, s. 242. 
w celu przełamania punktów obrony stałej księstwa. Równocześnie działania mieli podjąć rebelianci w centralnej Anglii oraz Szkoci, atakujący królewskie twierdze w północnej Anglii. Walki w Brytanii miały uniemożliwić wysłanie posiłków do Normandii i odwrócić uwagę króla od głównych działań. Natarcie dowodzone przez hrabiego Flandrii od strony północno-wschodniej miało wykorzystać rzekomą lukę w obronie i zdobyć Aumale oraz Drincourt. Około dwudziestu mil na południe miał uderzyć na Gournay brat hrabiego Flandrii Mateusz z Boulogne, po czym dołączyć do Flamandów. Na południowym wschodzie miał wkroczyć król Francji, by oblegając Verneuil i omijając silnie umocniony Vexin, zmierzać w kierunku serca Normandii - Rouen. Henryk Młody planował w tym czasie uderzyć na twierdzę Pacy, na południu Vexin. Natomiast na południowym wschodzie mieli równocześnie wkroczyć bretońscy buntownicy Ralfa de Fougères. Strategia napastników zakładała zneutralizowanie przygranicznych kluczowych punktów oporu, po czym planowano marsz na Rouen i zdobycie stolicy księstwa, co zachwiałoby zarówno potęga, jak i prestiżem Henryka Plantageneta. Jednoczesne natarcie Filipa Alzackiego na północy i króla Francji wraz z Ryszardem, Henrykiem II i Godfrydem od południa, miało „,wziąć w kleszcze” siły obrońców. Liczebność sił koalicjantów nie jest znana, ale warto zaznaczyć, że ich wojska składały się z feudalnego pospolitego ruszenia wspartego mieszczańską piechota, dlatego czas ich działania był ograniczony.

Inwazję na Normandię rozpoczęto w czerwcu 1173 r., kiedy wojska hrabiego Flandrii Filipa Alzackiego i jego brata Mateusza z Boulogne przekroczyły granicę na północnym wschodzie i obległy Aumale. Choć, jak podaje Wilhelm z Newburgh, garnizon twierdzy był silny, to jednak wkrótce po rozpoczęciu oblężenia, 29 czerwca, hrabia Aumale poddał miasto wraz z okolicznymi zamkami. Nasuwa się pytanie: Dlaczego dowódca warowni tak szybko skapitulował? Autor Historii Anglii wyjaśnia to chwiejną lojalnością hrabiego wobec "Starego Króla" 27 . Jednakże nie był to odosobniony przypadek przejścia wasala na stronę wroga i z tym problemem Henryk II musiał się liczyć. Spod Aumale Flamandowie wyruszyli na kolejną silną królewską twierdzę w Drincourt. Mury zamku były atakowane za pomocą machin oblężniczych przez kilka dni. Podobno flamandzka piechota była skuteczna w prowadzeniu oblężeń i szturmów na wały. Obrońcy miasta w końcu poddali się 21 lipca. Jednak szczęście nie

27 William of Newburgh The History of England (c. 1196), w: English Historical Documents online, t. 2: 1042-1189, eds. D.C. Douglas, G.W. Greenaway, Routledge 2015 s. 14 (to samo w: William of Newburgh, The History of English Affairs, w: The Church Historians of England, t. 4, cz. 2, tłum. J. Stevenson, London 1861, s. 486; M. Strickland, op. cit., s. 158. 
sprzyjało Mateuszowi z Boulogne, który podczas prowadzenia jednego z ostatnich szturmów został raniony bełtem w kolano i w wyniku infekcji rany zmarł wkrótce po zdobyciu zamku ${ }^{28}$. Śmierć brata i zarazem sukcesora tak wstrząsnęła hrabią Flandrii, że wycofał się na swoje ziemie, zadowalając się tylko spustoszeniem okolicznych miejscowości.

W międzyczasie na południu Henryk Młody próbował zdobyć zamki Pacy i Gournay broniące granicy Vexin normandzkiego. Nie osiągając jednak żadnych sukcesów, postanowił zwinąć oblężenie i dołączyć na południu do króla Francji atakującego Verneuil. To ważne strategicznie, silnie ufortyfikowane miasto bronione było przez liczny i zdeterminowany garnizon dowodzony przez królewskich konstabli Hugona de Lacy i Hugona de Beauchamp. Verneuil składało się z trzech Burghów, czyli warownych osad. Każdy oddzielony był od drugiego wysokimi kurtynowymi murami oraz fosami wypełnionymi wodą. Obronę uzupełniał także zamek ${ }^{29}$. Ludwik VII rozbił obóz od strony umocnień zwanych Wielkim Burghiem i w szybkim czasie wzniósł liczne machiny oblężnicze. Fosę próbowano zasypać kamieniami, a pod mury podciągnąć machinę oblężniczą jednak determinacja obrońców powstrzymała napastników. Silnie bronione pozycje skutecznie opierały się atakom i ostrzałowi wojsk francuskich. Król Francji nie był dobrym wodzem i nie potrafił przeprowadzać skutecznych szturmów na mury. Po zakończonych niepowodzeniem atakach liczył na zdobycie twierdzy głodem lub układami. Jednakże monarcha miał problemy z aprowizacją swoich wojsk. Zaopatrzenie zbierano i wysyłano prawdopodobnie z całej Francji. Oblężenie pod murami Verneuil trwało ponad miesiąc, aż do sierpnia, kiedy obrońcy, którym kończyła się żywność, poprosili monarchę o pertraktacje. Czyżby w twierdzy zaniedbano kwestie aprowizacyjne? Wydaje się, że do wyczerpania zapasów mogła się przyczynić znaczna liczba mieszkańców miasta i okolicznych uchodźców, których trzeba było nakarmić. Ludwik VII zgodził się na prośbę królewskich konstablów o trzydniowy rozejm, by obrońcy mogli poprosić o wsparcie Henryka II. Król Francji wraz z zięciem byli bowiem pewni, że „Stary Król” znajduje się wiele mil na północ i jest zaangażowany w walki z hrabią Flandrii, dlatego chętnie przystali na tę prośbę. Po upływie trzech

28 William of Newburgh, The History of English Affairs, s. 14, Jordan Fantosme, op. cit., s. 7; Gesta Regis Henrici, w: The Chronicle of Henry II and Richard I AD 1169-1192, ed. W. Stubbs, London 1867, s. 49.

${ }^{29}$ Roger of Hoveden, op. cit., s. 370; Gesta Regis Henrici II, s. 50. Po pierwszym ataku Ludwika VII na miasto w 1152 r. Henryk II wzmocnił Verneuil, tworząc silnie umocniony kompleks fortyfikacji. Warto dodać, że dwaj dowódcy twierdzy należeli do zaufanych i doświadczonych lordów z Irlandii. Natomiast mieszkańcy Verneuil zostali zmotywowani do lojalności królewskimi przywilejami. M.J. Strickland, op. cit., s. 164. 
dni twierdza miała zostać poddana na honorowych warunkach. Powtarzana podczas tego konfliktu praktyka rozejmów i nadmiernej ustępliwości, choć zgodna z honorowym prowadzeniem wojny w ówczesnych realiach, okazała się jednak zgubna dla agresorów. John Hosler wykazuje wspólny element strategii koalicjantów, polegający na odciągnięciu uwagi wojsk Henryka II i ofensywę na „punkt A”. Wtedy w krótkim czasie atakowano "punkt B”, będący teoretycznie daleko poza zasięgiem marszu wojsk obrońców ${ }^{30}$. Założenia strategiczne planu napastników okazały się jednak całkowicie nietrafione, gdyż tracono sporo czasu i środków na próby zdobycia granicznych twierdz oraz, błędnie zakładano, że wróg znajduje się bardzo daleko, co mogło być spowodowane brakiem szpiegów lub skutecznego zwiadu. Ponadto wojska króla Ludwika VII unikały walnych starć w polu, skupiając się na oblężeniach stałych punktów oporu.

Jaka zatem była odpowiedź Henryka II Plantageneta na inwazję skierowaną z kilku stron na granice Normandii? Przede wszystkim król Anglii wykazał się zimną krwią i opanowaniem godnym znakomitego stratega. Zamierzał czekać na posunięcia wrogów, ufając sile swych zamków i miast, które wiążąc wrogie wojska w długie oblężenia, dawały czas niezbędny do przeanalizowania sytuacji oraz zebrania wojsk. Ostentacyjnie udawał bierność i brak zdecydowanych działań, oddając się polowaniu w pobliżu Rouen. Tymczasem w tajemnicy wydawał dyspozycje do dowódców w Anglii i na kontynencie, ściągał zapasy oraz wzmacniał warownie. Udał się do Brytanii, gdzie przebywał tylko przez pięć dni, zbierając w tym czasie potężne wojska. Swoją armię oparł głównie na zaciągach najemników, cieszących się opinią niezwykle skutecznych i lojalnych (dopóki otrzymywali żołd) zbrojnych, określanych wówczas mianem routiers, czyli "łupieżców”, "pustoszycieli". Chociaż owa nazwa była niewątpliwie synonimem złej sławy, jaką cieszyły się wojska najemne cudzoziemskiego pochodzenia ${ }^{31}$, były to jednak formacje szybsze, lepiej zdyscyplinowane i bardziej skuteczne zarówno w bitwach w polu, jak i w oblężeniach ${ }^{32}$. Dzięki ogromnym zasobom królewskiego skarbca Henryk II najął błyskawicznie znaczny kontyngent najemnych Brabantczyków. Jordan Fantosme podaje liczbę 10 tys. wynajętych najemników

${ }^{30}$ J.D. Hosler, Henry II, s. 203-204.

31 Najemników głównie rekrutowano w XII i XIII w. z obszarów Brabancji, Flandrii, Pogranicza Cesarstwa i Walii. Stąd też czasem nazywano ich Brabantczykami, Flamandami itp.

32 J.D. Hosler, Revisiting Merceneries under Henry Fitz Empress 1167-1188, w: Merceneries and Paid Men. The Mercenary Identity in the Middle Ages, Proceedings of a Conference held at University of Wales, Swansea, $7^{\text {th }}-9^{\text {th }}$ July 2005, ed. J. France, Leiden-Boston 2008, s. 33. 
brabanckich oraz zaciagi rycerzy z Andegawenii i Gaskonii ${ }^{33}$. Roger z Hoveden szacuje liczebność kontyngentu najemnego na 20 tys. Jednak są to liczby z pewnością zawyżone. Jacques Boussard na podstawie badań zapisów Pipe Rolls Henryka II określa liczbę najemników na królewskim żołdzie w latach 1173-1174 na 6 tys. zbrojnych. Możemy zatem przyjąć, że w letniej kampanii obronnej uczestniczyło ok. 2-3 tys. zaciężnych ${ }^{34}$. Szeregi królewskiej armii uzupełniono także o kontyngenty członków familia regis i lokalnych lojalnych feudałów. Jest natomiast pewne, że trzon sił i decydujące znaczenie podczas kampanii obronnej miały oddziały najemników. Thomas Jones przedstawia nawet tezę, że Henryk II wcale nie użył feudalnych zaciągów, tylko polegał na zwerbowanych Brabantczykach i Walijczykach ${ }^{35}$. Szukając analogii do działań wojsk rojalistów w Anglii składających się z pospolitego ruszenia feudalnego oraz milicji miejskich, bardziej skłaniam się ku tezie wykorzystania pewnej liczby sił feudalnych, chociażby tych rycerzy i zbrojnych, którzy operowali na terenie Normandii już wcześniej lub posiadali tam ziemie i opowiedzieli się za Henrykiem Starszym. Istotne jest jednak, że to ,ż̇ołnierze fortuny" byli trzonem wojsk króla Anglii, który potrafił nie tylko błyskawicznie ich zwerbować, ale też sprawnie wykorzystywać ich atuty bojowe.

Plantagenet szybko przerzucił swoje siły przez kanał la Manche do normandzkiego portu w Barfleur, pozostawiając walkę z buntownikami w środkowej Anglii oraz odparcie szkockiej inwazji w Northumberlandzie doświadczonemu i lojalnemu doradcy - justycjariuszowi Ryszardowi de Lucy.

Po wylądowaniu wraz z wojskami Henryk II wyruszył na zachód w kierunku obleganego Drincourt. Granica północno-wschodnia od strony Flandrii była najsłabszym ogniwem obrony, dlatego król postanowił poprowadzić kontrnatarcie w tamtym kierunku. Podczas marszu doszły go jednak wieści o wycofaniu się hrabiego Filipa Alzackiego. Wówczas monarcha skierował swoją armię w kierunku Verneuil. Po drodze wojska królewskie obległy i praktycznie z marszu szturmem zdobyły zamek Breteuil należący do jednego ze zbuntowanych baronów - Roberta, earla Leicester. Błyskawiczne zdobycie zamku mogło być spowodowane zaskoczeniem wskutek nagłego przybycia w ten rejon Normandii Henryka II. Nie udało się jednak pojmać spiskowca, gdyż Robert uciekł z zamku. Poirytowany król Anglii rozkazał spalić fortecę. W międzyczasie dotarł do niego posłaniec z Verneuil z prośbą o przyjście miastu z odsieczą i in-

${ }^{33}$ Jordan Fantosme, op. cit., s. 5.

${ }^{34} \mathrm{~J}$. Boussard, Les mercenaires au XII siècle: Henri II Plantagenêt et les origins de l'armée de métier, w: Bibliothèque de l'école des Chartes 106 (1945-1946): 189-224, s. 220.

35 T.M. Jones, The Generation Gap of 1173-74: The War between the Two Henrys, "Albion" 1973, 5, s. 37. 
formując o zawartym ultimatum. Henryk II niezwłocznie wymaszerował z wojskami w kierunku miasta. Tymczasem Ludwik VII złamał postanowienia układu i uwięził zakładników. Chociaż zamek pozostał nietknięty, król Francji według Rogera z Hoveden wkroczył do miasta trzeciego dnia rozejmu, 9 sierpnia i łamiąc dane słowo, uwięził wszystkich obrońców Wielkiego Burghu, a osadę podpalił, prawdopodobnie by zyskać „,zasłonę dymną" podczas odwrotu ${ }^{36}$. Przedtem przezornie wysłał na czele zwiadu arcybiskupa Sens Willhema, earla Henryka II i Tybalda w stronę wojsk Henryka II, by obserwowali jego poczynania. Czy posłańcy wysłani od zwiadowców nie dotarli do króla Francji z alarmującą wieścią, czy też władca andegaweński w niewiadomy sposób wyminął szpiegów - tego nie wiadomo, pewne jest natomiast, że Francuzi zupełnie nie spodziewali się jego wojsk w tym rejonie. Również Henryk II wysłał przodem zwiadowców, by szpiegowali pozycje wroga, bowiem dobre rozpoznanie poczynań nieprzyjacielskich wojsk było podstawą planowania taktyki bitewnej króla Anglii. Henryk II zawsze dążył do walnej bitwy i bezpośredniej konfrontacji z wrogiem w polu. Jego wojska we wzorowym szyku bojowym pojawiły się nagle na wzgórzach nieopodal miasta. Zaskoczony Ludwik VII wpadł w panikę i zarządził odwrót. Tymczasem jazda Henryka II natarła na francuski obóz, masakrując uciekających wrogów ${ }^{37}$. Aż do nadejścia zmroku Henryk II ścigał Francuzów, wycinając kompletnie ich tylną straż. W zdobytym obozie znaleziono mnóstwo zaopatrzenia: ziarno, wino i inną żywność, a także porzucony różnorodny ekwipunek ${ }^{38}$.

Dlaczego Ludwik VII posiadający silną armię wycofał się w popłochu zamiast stawić czoło wojskom Henryka II? Czy aż tak obawiano się osoby króla Anglii i jego sztuki wojennej? Czy może lęk wzbudzali zabójczo skuteczni najemnicy króla? Zaskakujące jest, że Ludwik VII, będąc doświadczonym dowódca, weteranem licznych kampanii we Francji, a także krzyżowcem uczestniczącym wcześniej w II krucjacie, nie dość, że zlekceważył przeciwnika, sądząc, iż jest on daleko, to jeszcze w panice uszedł z pola bitwy zamiast natychmiast ustawić swoje wojska i przy wsparciu obozu i zdobytego miasta bronić pozycji ${ }^{39}$.

36 Roger of Hoveden, op. cit., s. 371.

37 Ibidem; Ralph de Diceto, op. cit., s. 375; William of Newburgh, The History of England, s. 15. Wilhelm z Newburgha podaje nawet, że Ludwik VII wysłał posłańców w stronę wojsk anglo-normandzkich, by wybadali, czy na czele armii stoi sam Henryk II. Angielski monarcha pewny siebie, objeżdżając czoło swych wojsk, wykrzyknął do nieprzyjacielskich zwiadowców: ,„jedźcie i powiedzcie swojemu królowi, że jestem tutaj osobiście”.

38 Ibidem.

39 Jak widać zdobyte doświadczenie nie przyczyniło się wcale do poprawy dowodzenia francuskiego monarchy. Główne przyczyny klęsk Ludwika VII spowodowane były strachem przed podjęciem ryzyka walnej bitwy (jest to częste zjawisko w omawianym 
Choć wróg poniósł dotkliwe straty i zagrożenie ze strony króla Francji oraz hrabiego Flandrii minęło, nie był to koniec kampanii. Triumfalnie wracającego do Rouen Henryka II doszły wieści o wkroczeniu do księstwa Bretończyków pod dowództwem Ralfa de Fougères i earla Hugona z Chester, którzy prowadzili natarcie w kierunku Avranches. Z niewiadomych przyczyn atak od strony Bretanii opóźnił się, dlatego Plantagenet mógł po pokonaniu pozostałych koalicjantów zająć się kolejnymi „intruzami”. Kierując się na północ, zlikwidował kolejny ośrodek oporu, zdobywając zamek Damville należący do Gilberta de Tillières. Henryk II wkrótce wznowił marsz do Rouen, gdzie zamierzał przegrupować siły i uzupełnić zapasy, a także zapewne pozostawić zdobyte na Francuzach łupy. Stamtąd zamierzał też kierować dalszymi poczynaniami swych wojsk w obronie swojego władztwa. W kierunku rebeliantów z Bretanii natychmiast wysłał Wilhelma de Humet'a, syna Ryszarda de Humet'a, konstabla Normandii. Królewskiemu dowódcy towarzyszyła brabancka jazda i zbrojni z Normandii ${ }^{40}$. Za poruszającym się szybko kontyngentem jazdy miał wkrótce wyruszyć oddział królewski wraz z taborami - zaopatrzeniem i machinami niezbędnymi do skutecznego przeprowadzenia oblężenia. Ralf de Fougères i earl Chester wyruszyli na czele wojsk naprzeciw siłom Henryka. Obie armie spotkały się 20 sierpnia w pobliżu miasta Dol i ustawiły w szyku bojowym. Bitwę rozpoczęła brabancka jazda de Humet’a, która szarżując na wrogie wojska, rozbiła szyk Bretończyków, wielu z nich wybijając i zmuszając do chaotycznej ucieczki. Wodzowie bretońscy pospiesznie uszli z pogromu wraz z co znaczniejszymi rycerzami, znajdując schronienie w twierdzy Dol. Według relacji Rogera z Hoveden: „W tej bitwie zostało pojmanych przez Brabantczyków siedemnastu znamienitych rycerzy, słynących ze swojej dzielności [...]. Oprócz tego wielu było pojmanych, zarówno konnych, jak i pieszych i więcej niż piętnaście setek Bretończyków zostało zgładzonych"41. Dowiadujemy się zatem, że straty były znaczne oraz że wróg wystawił nie tylko jazdę, lecz także piechotę, podczas gdy wojska królewskie dysponowały wyłącznie jazdą. Nie wiemy, co zadecydowało o tak szybkim zwycięstwie Brabantczyków nad Bretończykami. Można wysnuć hipotezę, że najemna jazda tak łatwo rozbiła szyki wroga dzięki lepszej dyscyplinie i wyszkoleniu bojowemu.

okresie) oraz niezdecydowaniem króla w kluczowych momentach walk. Poza tym Kapetyng ulegał wpływom swoich doradców wojennych. Por. M.J. Strickland, op. cit., s. 166; J.D. Hosler, Henry II, s. 204-205 oraz S. Isaac, Cowardice and Fear Management: The 1173-74 Conflict as a Case Study, w: The Journal of Medieval Military History, t. 4, eds. C.J. Rogers, K. DeVries, J. France, Woodbridge 2006, s. 59-60.

40 William of Newburgh, The History of England, s. 15; Roger of Hoveden, op. cit., s. 371.

${ }^{41}$ Roger of Hoveden, op. cit., s. 372 (tłum. autor). 
Być może rebelianci zostali zaskoczeni i ich gorzej wyszkolone wojska nie zdążyły ustawić się w porę w szyku bojowym ${ }^{42}$.

Po zakończeniu pościgu wojska królewskie obległy Dol, a najemnicy otoczyli twierdzę ścisłym kordonem. Wilhelm de Humet czekał z atakiem na przybycie króla, prawdopodobnie posyłając wiadomość do Henryka II. Gdy wieści o zamknięciu Bretończyków w obleganym Dol doszły do Plantageneta, ten niezwłocznie zarządził wymarsz i po trzech dniach dotarł pod miasto i zamek, znów kompletnie zaskakując swych wrogów, z niepokojem obserwujących przybywającego na czele wojsk króla, wydającego niezwłocznie rozkaz ustawienia machin miotających kamienie. Z przekazów źródłowych można wywnioskować, co jest trudne do uwierzenia (spodziewano się, że Henryk II przebywa we wschodniej Normandii) , że w ciągu trzech dni pokonał dystans ok. 270 kilometrów! I to z ciężkimi taborami wiozącymi zaopatrzenie i machiny niezbędne do prowadzenia oblężenia. Nawet jeśli monarcha przebywał bliżej, a jazda walcząca pod Dol została wysłana przed głównymi siłami, był to i tak imponujący oraz niewiarygodny wyczyn ${ }^{43}$. Szybkość manewru króla Anglii wzbudziła strach wśród obrońców do tego stopnia, że przed przystąpieniem Henryka II do ataku, skapitulowali. Być może obawiano się licznych machin miotających, które poradziłyby sobie ze słabymi fortyfikacjami twierdzy. Do niewoli dostało się ponad osiemdziesięciu rycerzy, w tym przywódcy rebelii, Ralf de Fougères i earl Hugon z Chester ${ }^{44}$.

Po wycofaniu się Flamandów, rozbiciu Francuzów i panicznej ucieczce Ludwika VII oraz zneutralizowaniu zagrożenia ze strony Bretanii triumfujący Henryk II mógł już tylko zająć się pacyfikacją ostatnich rebelianckich zamków. Zdobycze buntowników były nikłe, a straty znaczące. Również w królestwie Anglii wojska królewskie osiągnęły sukcesy, zdobywając kolejne twierdze buntowników i wypierając Szkotów, z którymi zawarto rozejm mający trwać aż do lata $1174 \mathrm{r}$. Także pozostali koalicjanci, na czele z Ludwikiem VII, szukali sposobności, by przez rokowania pokojowe zapobiec dalszym klęskom i stratom lub prawdopodobnej inwazji odwetowej na tereny Flandrii i Francji. Nim jednak doszło do rokowań,

42 W.L. Warren, op. cit., s. 128 oraz J.D. Hosler, Henry II, s. 144.

${ }^{43}$ Matthew Strickland podaje tezę o zabraniu machin i części wojsk z pobliskich terenów, tłumacząc niewiarygodne tępo marszu relacjonowane przez kronikarzy. M.J. Strickland, op. cit., s. 169. Dobry system i stan dróg, sprawna logistyka (wymiana koni) mogły oczywiście sprzyjać błyskawicznym przemieszczeniom, ale podany dystans i czas jest niemożliwy do przebycia na ówczesne warunki. Jednak podobnie szybkie manewry stosował zarówno wcześniej król Stefan podczas walk ze zwolennikami Matyldy, jak i później Ryszard Lwie Serce walczący na terenie Normandii i Maine pod koniec XII w.

44 Listę pojmanych wymienia Roger z Hoveden. Zob. Roger of Hoveden, op. cit., s. 373; Ralph de Diceto, op. cit., s. 378; Jordan Fantosme, op. cit., s. 11. 
24 września oddział rycerzy Henryka II starł się z francuskimi rycerzami pomiędzy Gisors a Courcelles, gdzie Anglo-Normanowie pokonali Francuzów i pojmali Engelrama, kasztelana Trie, którego doprowadzono do „Starego Króla”45. Rycerze królewscy musieli prowadzić wypad lub pościg już na terytorium francuskim - po drugiej stronie rzeki Epte. Nazajutrz rozpoczęto rokowania na zjeździe odbywającym się między Gisors a Trie. Na spotkaniu, oprócz Henryka II i Ludwika VII, zjawili się młodzi Plantageneci oraz liczna grupa możnych i dostojników kościelnych. Mimo że Henryk II po swoich zwycięstwach był na wyraźnie lepszej pozycji, zamierzał zaproponować swoim synom wspaniałomyślne warunki. Zawsze wierzył w to, że jego rodzina może ponownie zjednoczyć się przeciw zewnętrznym wrogom i miał nadzieję, że synowie ostatecznie opuszczą wrogi obóz. Propozycja króla Anglii była następująca: Henryk Młody miał otrzymać połowę dochodów z Anglii i tamże cztery zamki lub połowę wpływów z Normandii i po jednym zamku w Andegawenii, Maine oraz Turenii. Można łatwo dostrzec przenikliwość króla Anglii, który celowo nie zaproponował np. czterech normandzkich zamków, gdyż były one zbyt ważne strategicznie do obrony księstwa. Ryszardowi ojciec zaproponował połowę dochodów z Normandii i cztery tamtejsze zamki, natomiast Godfryd miał otrzymać całą Bretanię po ślubie z Konstancją córką bretońskiego diuka Konana $\mathrm{IV}^{46}$. Niechętny wobec tych warunków był oczywiście Ludwik VII, który namawiał synów Henryka II do odrzucenia propozycji. Negocjacje w gwałtowny sposób przerwał jednak Robert, earl Leicester, wykrzykując obraźliwe słowa do Henryka II i wymachując mieczem, jak wspomina Roger z Hoveden, z zamiarem uderzenia króla, jednak w porę powstrzymali go świadkowie ${ }^{47}$. Było wiadome, że gdyby zawarto ugodę, Robert de Beaumont zostałby pozbawiony wszystkich ziem, toteż działania wojenne wznowiono. Porywczy earl Leicester wkrótce po zerwaniu rokowań wynajął spory kontyngent flamandzkich najemników i popłynął do Wschodniej Anglii, jednak został pokonany i pojmany przez siły królewskie w bitwie pod Fornham.

Tymczasem Henryk II nie wstrzymał się zwyczajowo z prowadzeniem działań wojennych na czas zimy i w listopadzie z kontyngentem najemników wkroczył do Andegawenii, zdobywając zamki La Haye, Preuilly i Champigny. Co ciekawe, zbuntowani panowie sami poddawali swoje twierdze i do niewoli dostało się wielu andegaweńskich rycerzy ${ }^{48}$.

\footnotetext{
45 Roger of Hoveden, op. cit., s. 373; Gesta Regis, s. 60.

46 Roger of Hoveden, op. cit., s. 373; J. Gillingham, Ryszard Lwie Serce, s. 67.

47 Roger of Hoveden, op. cit., s. 373.

48 Ibidem, s. 375-374.
} 
Następnie król wyruszył do Vendôme, by zabezpieczyć ten ważny graniczny region. Hrabia Vendôme był lojalny wobec Henryka II, jednak został obalony przez swojego syna Bucharda de Lavardin, który przejął władzę i dołączył do rewolty. Król Anglii zdobył miasto Vendôme, biorąc do niewoli uzurpatora i jego licznych popleczników. Na początku $1174 \mathrm{r}$. rebelia na kontynentalnych ziemiach Plantagenetów została praktycznie zdławiona. Koalicjanci kontrolowali już tylko ziemię przy południowej granicy Normandii ${ }^{49}$. Stało się jasne, że kluczowe działania wojenne będą znów toczyć się na terenie księstwa, a inwazja może nadjeść ze wschodniej lub północno-wschodniej granicy od strony Francji i Flandrii. Koalicjanci postanowili w styczniu 1174 r. wykorzystać nieobecność w Normandii angielskiego króla i z rebelianckich terytoriów Bellême na południowej granicy księstwa uderzyli na Séez. Cel ataku nie był przypadkowy. Jak wskazuje W.L. Warren, miasto znajdowało się na strategicznie ważnym szlaku komunikacyjnym i po zdobyciu mogło stać się bazą do wiosennych ataków w kierunku północnym na Falaise, Argentan i Lisieux oraz umożliwić wsparcie inwazji króla Francji ${ }^{50}$. Atak z zaskoczenia, który poprowadził Henryk Młody, hrabia Flandrii Filip, zaciekły opór mieszkańców Séez oraz zimowa aura i problemy z transportem zapasów zniweczyły plany koalicjantów i zmusiły ich do wycofania się spod murów miasta ${ }^{51}$. Główne działania wojenne miały zostać wznowione wraz z wygaśnięciem rozejmu, po Wielkanocy, czyli 24 marca, kiedy odwilż mogłaby umożliwić przemieszczanie się wojsk.

Latem sojusznicy postanowili znów postawić na wcześniejszą strategię trzymania Henryka II z dala od głównych terenów ataków i próby zdobycia Rouen. Aby tego dokonać, król Anglii musiał zostać zmuszony do przyjścia z odsieczą Anglii i do opuszczenia Normandii. Miał w tym pomóc skoordynowany atak Szkotów i rebelianckich baronów, mających dążyć do połączenia armii i zdobycia najważniejszych królewskich twierdz w środkowej i północnej Anglii. Było to realne przedsięwzięcie, gdyż Wilhelm Lew mógł wciąż zmobilizować liczną armię, bowiem w kampanii poprzedniego roku nie poniósł zbyt wielkich strat. Tymczasem Henryk II spodziewał się zapewne ataku na Normandię, lecz, tak jak wcześniej, wzmocnił garnizony twierdz i ufał, że system obrony znowu skutecznie zatrzyma inwazję, a on zbierze siły i będzie dążył do starcia w polu. Udał się do Maine i Andegawenii, by wzmocnić graniczne zamki, wypędzając przy okazji zbrojnych swego syna Ryszarda z Saintes w Poitou. Z począt-

\footnotetext{
49 W.L. Warren, op. cit., s. 132; J.D. Hosler, Henry II, s. 211.

50 W.L. Warren, op. cit., s. 132.

51 Ralph de Diceto, op. cit., s. 379.
} 
kiem lata, gdy wygasł rozejm ze Szkotami, król Wilhelm Lew ponownie uderzył na Northumberland, jednak tym razem sytuacja na północy Anglii stała się niepokojąca. Szkoci zdobyli siedem zamków, z dwoma zawarli rozejm, na mocy którego, jeśli nie nadeszłaby odsiecz, miały się po czasie poddać oraz oblegali kolejnych dziesięć królewskich twierdz. Na domiar złego część północnych feudałów, w tym biskup Durham Hugon de Puiset, przeszło na stronę wroga. O niebezpiecznej sytuacji na północy królestwa alarmował króla Ryszard z Ilchester, błagając, by Henryk II przybył z odsieczą. Zagrożenie spotęgował fakt, że Filip Alzacki zebrał flamandzkie wojska i pomaszerował do Gravelines, skąd zamierzał popłynąć do północnej Anglii, by wesprzeć Szkotów ${ }^{52}$. Jednak niesprzyjający wiatr uniemożliwił mu dokonanie inwazji na Wyspie i w końcu hrabia Flandrii połączył swe siły z królem Francji oraz z „Młodym Królem”. Zaniepokojony wieściami Henryk Starszy dał się przekonać swoim zaufanym doradcom i wypłynął do Anglii 8 lipca. Na taką okazję właśnie czekali koalicjanci.

Przekroczyli granice Normandii na wschodzie i oblegli Rouen, aby zdobywając to ",serce księstwa", mieć atut w rokowaniach z Henrykiem II. Położone nad Sekwaną duże i silnie umocnione miasto otoczone było z jednej strony skalistymi ostrogami, co było pomocne dla obrońców, gdyż byli zabezpieczeni przed atakiem z kilku stron, ale jednocześnie pozwalało to łatwiej otoczyć twierdzę szczelnym kordonem przez wrogie wojska. Miasto było jednak rozległe i wojska francusko-flamandzkie nie zdołały całkowicie go otoczyć. Według Wilhelma z Newburgha do Rouen docierały zapasy, płynąc przez Sekwanę przez jedno z dwu wejść, ku zazdrości wrogich wojsk $^{53}$. Oblegający wiedzieli, że zdobycie twierdzy nie będzie łatwe oraz że muszą się spieszyć i sforsować mury, zanim zza kanału La Manche przybędzie król Anglii. Ustawiono machiny oblężnicze, wykopano rowy w celu obwarowania obozu i podzielono wojska na trzy części. Każdy oddział miał być w gotowości i prowadzić ataki przez osiem godzin, zaś później zmieniał go kolejny kontyngent. Ta taktyka miała zapewnić zmieniającym się atakującym odpoczynek oraz zmusić obrońców do wyczerpania ciągłą gotowością bojową. Garnizon i mieszkańcy miasta nie dawali jednak za wygraną i tak zaciekle bronili murów, że szturmy prowadzone często dniami i nocami nie przynosiły efektów. W końcu, by zyskać nieco wytchnienia, bohaterscy obrońcy poprosili Ludwika VII o dzień rozejmu w dzień Świętego Laurencjusza, aby świętować wspomnienie męczennika. Pobożny król Francji zezwolił na rozejm i mieszkańcy mogli odpocząć od trudów walki.

52 Jordan Fantosme, op. cit., s. 21.

53 William of Newburgh, The History of England, s. 19. 
Podobno na przedpolu miasta zorganizowano nawet turniej rycerski i to na oczach wrogich wojsk. Ludwik VII, być może za namową hrabiego Flandrii, jednak zerwał rozejm, zamierzając skrycie zaatakować niechronione mury obronne świętującego miasta. Podstęp jednak się nie udał, gdyż pewien klerk siedzący na wieży jednego z kościołów w porę dostrzegł francuskich zbrojnych podkradających się do murów i zaalarmował dzwonem obrońców. Podstępni napastnicy już wspinali się na ich szczyty, gdy nagle na murach pojawili się obrońcy i zaciekle walcząc, odparli szturmujących ${ }^{54}$. Koalicjantom pozostało czekać, aż wyczerpią się zapasy oraz siły mieszkańców i dojdzie do kapitulacji.

W tym czasie Henryk II, którego podczas wojny nie opuszczało szczęście, dzięki nieprawdopodobnie wręcz szczęśliwemu zbiegowi wydarzeń błyskawicznie zakończył wojnę domową i inwazję na północy Anglii. Zamiast wyruszyć do boju ze Szkotami, Henryk II udał się do Canterbury, gdzie przy grobie św. Tomasza Becketa publicznie dokonał aktu pokuty. Nazajutrz otrzymał radosną wiadomość, że rycerze królewscy pod wodzą Ranulfa de Glanville'a, atakując z zaskoczenia, pojmali pod Alnwick króla Szkocji Wilhelma i jego straż przyboczną. Na wieść o uwięzieniu swego wodza i monarchy Szkoci uciekli lub skapitulowali, a wielu rebeliantów poddało swoje fortece, prosząc króla o łaskę.

Gdy nagle minęło zagrożenie w królestwie Anglii, Henryk II postanowił błyskawicznie wrócić do Normandii, by przyjść z odsieczą mieszkańcom Rouen. Zebrał znaczny kontyngent składający się z wiernych członków królewskiej famila, najemnych Brabantczyków i tysiąca Walijczyków ${ }^{55}$. Rycerze przyboczni pochodzili prawdopodobnie ze zwyczajowych zaciągów służących 40 dni. Król zabrał ze sobą też swoich jeńców, Wilhelma Szkockiego, Roberta de Beaumont i Ralfa de Fougères, których umieścił w lochach Falaise, a następnie Caen. Jak sugeruje Wilhelm z Newburgha, król niejako celowo wylądował z wielką pompą i rozgłosem w Barfleur, by wieści o jego przybyciu dotarły pod Rouen i przestraszyły jego wrogów ${ }^{56}$. Ten sam autor sugeruje, że wiadomości o klęsce króla Szkotów i rychłym przybyciu Henryka II do Normandii dotarły już kilka dni wcześniej do obozu koalicjantów pod Rouen, ci jednak ufni w siłę swoich wojsk kontynuowali oblężenie ${ }^{57}$.

Tymczasem Henryk II, zanim wyruszył z głównymi siłami pod obleganą stolicę Normandii, wysłał nocą oddział Walijczyków, którzy mieli

\footnotetext{
54 Ibidem, s. 19-20.

55 Roger of Hoveden, op. cit., s. 384.

56 William of Newburgh, The History of England, s. 20.

57 Ibidem.
} 
przekroczyć Sekwanę, dokonać zwiadu i przygotować drogę królewskim siłom głównym. Walijscy wojownicy, doświadczeni w walkach z Anglikami po rodzimych puszczach i bagnach, byli mistrzami w organizowaniu zasadzek i wojnie szarpanej ${ }^{58}$. Harcownicy niepostrzeżenie przeszli puszczę i dotarli do wrogich linii zaopatrzeniowych, gdzie na dogodnej pozycji z zasadzki zaatakowali konwój wiozący prowiant dla wojsk pod murami Rouen. Lekkozbrojni najemnicy odnieśli sukces, zabijając licznych nieprzyjaciół, wyrzynając konie oraz niszcząc ekwipunek i zapasy $^{59}$. Po ataku wycofali się i ukryli w gęstych lasach. Utrata cennych taborów z zaopatrzeniem spowodowała widmo głodu dla oblegającej armii, zwłaszcza że otaczające obóz lasy roiły się od Walijczyków i obawiano się wszelkich wypraw po aprowizację na pobliskie ziemie. Obawy były jak najbardziej słuszne, bowiem z relacji Wilhlema z Newburgha wiadomo, że pewnego dnia wdarli się nawet do środka obozu francuskiego, zabijając ponad setkę zbrojnych ${ }^{60}$. W tym czasie Henryk II z przybocznymi i kontyngentem Brabantczyków przypłynął od strony niechronionego zachodu miasta i wraz z garnizonem przygotowywał główny atak. Podczas gdy oblegający zajęci byli odpieraniem Walijczyków, piechota królewska za pomocą faszyny, belek, ziemi oraz kamieni zasypała wykopane przez Francuzów rowy, umożliwiając przejście i obsadziła mury obronne, spodziewając się kontrataku ${ }^{61}$, który jednak nie nadszedł. Spanikowani wrogowie stłoczyli się wśród namiotów i spalili w obozie machiny oblężnicze ${ }^{62}$. Ludwik VII wysłał część swoich wojsk do Francji i nazajutrz 9 sierpnia poprosił o rozejm oraz rozpoczęcie rozmów pokojowych. Na miejscu spotkania wyznaczonym na trakcie między Rouen a Tostes król Francji nigdy się jednak nie pojawił, uchodząc z resztką swoich wojsk przez granicę. Było jasne, że koalicja upadła, tracąc ostatnie siły, środki i możliwości. Jedynie młody Ryszard wciąż jeszcze oblegał królewskie zamki w Poitou i mimo opuszczenia przez braci oraz Ludwika VII nie dawał za wygraną. Pozostali pokonani sojusznicy zawarli z Henrykiem II pakt o zawieszeniu broni trwający od 8 do 29 września. „Stary Król” mógł zdusić upór swego syna i po raz kolejny podczas tej wojny przybył nagle ze swoimi wojskami, z zaskoczenia atakując kwaterę Ryszarda w Saintes, zdobywając szturmem miasto i zmuszając syna do ucieczki ${ }^{63}$. Młody Plan-

58 "Ludzie tej rasy byli sprawni i biegli w poruszaniu się po lesie" - William of Newburgh, The History of England, s. 20.

59 Roger of Hoveden, op. cit., s. 384; William of Newburgh, History of England, s. 20.

60 Ibidem.

61 Roger of Hoveden, op. cit., s. 384; Ralf de Diceto, op. cit., s. 386.

62 William of Newburgh, The History of England, s. 20.

63 Zob. J. Gillingham, Ryszard Lwie Serce, s. 68-69. 
tagenet, po licznych nieudanych próbach stawiania oporu i ucieczkach przed pościgiem, w końcu 23 września przybył do swego ojca, błagając go ze łzami w oczach o przebaczenie. Wojna została zakończona, a zawarty $\mathrm{w}$ Montlouis traktat pokojowy oznaczał przywrócenie status quo ante bellum na 15 dni przed wybuchem konfliktu. I znowu „Stary Król” okazał się wspaniałomyślny, oferując jednak synom mniej niż wcześniej: Henrykowi Młodemu 15 tys. funtów andegaweńskich i dwa zamki w Normandii, Ryszardowi dwie nieufortyfikowane rezydencje i połowę wpływów z Poitou, a Godfrydowi połowę dochodów Bretanii. Jeńcy zostali pod przysięgą wypuszczeni i nie mogli odbudować swoich zamków. Król Szkocji na mocy traktatu z 1174 r. zawartego w Falaise oddał pięć szkockich zamków i złożył hołd lenny Henrykowi. Lojalni baronowie i mieszczanie zostali natomiast przez króla chojnie obdarowani ${ }^{64}$.

Próba pokonania ,,imperium Plantagenetów”, poprzez osłabienie jedności wewnątrz rodziny królewskiej oraz zbuntowanie wasali, wsparta inwazją na kilku frontach, spełzła na niczym. Chociaż zaciekła obrona twierdz Northumberlandu przed Szkotami była istotna, a zwycięstwa rojalistów pod Fornham i Alnwick okazały się poważnym ciosem dla koalicjantów, to jednak uważam, że kluczowe do odwrócenia losów wojny na korzyść Henryka II były działania na terenie Normandii i triumfy pod Verneuil, Dol oraz Rouen. Strategia ataku na księstwo, polegająca na nieskutecznym obleganiu twierdz granicznych i marszu na Rouen, zawiodła sojuszników, choć hrabia Flandrii wraz z hrabią Boulogne zdobyli na początku ważne północne twierdze w Drincourt i Aumale. Koalicji kierowanej przez Ludwika VII brakowało skutecznego i jednolitego dowództwa, a także skoordynowania poszczególnych ataków. Zaniedbanie rozpoznania oraz szybkości manewrów wojsk "Starego Króla” i błędne przypuszczenia, że angielski monarcha znajduje się poza zasięgiem operacyjnym, przyczyniły się do klęski. Ponadto król Francji okazał się nieudolnym dowódca, niepotrafiącym zachować dyscypliny w swojej armii, a także prowadzić skutecznych ataków na warownie, mimo posiadania machin oblężniczych. Problemem dla Francuzów podczas kampanii, zwłaszcza w trakcie oblężenia Rouen, była także aprowizacja i zaniedbanie kwestii kontrolowania linii zaopatrzeniowych, co z kolei pozwoliło królowi Anglii bez przeszkód nękać wrogie transporty.

Analizując przebieg kampanii na terenie księstwa Normandii, w której bezpośrednio dowodził Henryk II, można wysnuć wiele wniosków na temat sztuki wojennej monarchy. System obronny terytorium zasadniczo spełnił swoją rolę, osłabiając impet ataków wroga oraz wiążąc siły koali-

${ }^{64}$ Zob. W.L. Warren, op. cit., s. 136-138. 
cjantów przez długi czas. Jedynym słabym elementem okazały się mniej ważne zamki normandzkich rebeliantów, a także przedwczesna kapitulacja Aumale. Na ogół jednak królewskie garnizony przed rozpoczęciem działań wojennych, wzmocnione przez monarchę, zaciekle broniły ważnych granicznych twierdz, a opór stałych punktów obrony pozwolił królowi na zmobilizowanie posiłków i przerzucenie ich okrętami z Anglii. Ponad to Henryk II, zdając sobie sprawę z planów ataku na długich granicach, czekał spokojnie na pierwszy ruch przeciwników, by odpowiednio zareagować. Na uwagę zasługuje również główna strategia królewska, polegająca na osobistym przewodzeniu „pogotowiem uderzeniowym”, kierowanym w najbardziej zagrożone punkty obrony. Henryk nie mógł reagować wszędzie, dlatego do działań wysyłał zaufanych dowódców, wtajemniczonych w założenia królewskiej taktyki i strategii.

Zadziwia nieprawdopodobna wręcz, zwłaszcza jak na realia średniowiecza, zdolność do szybkiego przerzucania wojsk, błyskawiczne marsze i zaskoczenie niczego niespodziewających się nieprzyjaciół. Nasuwa się jednak pytanie, jak w ówczesnych realiach zwycięski władca tego dokonał. Z pewnością znał teren i kontrolował solidny system dróg $\mathrm{w}$ księstwie. Ponadto, jak wspomniano, miał do dyspozycji stałą flotę pomagającą w kontakcie z Anglią. Wiadomo również, że dysponował bazami, w których zmieniano zmęczone konie. Zaryzykuję stwierdzenie, że główne siły uderzeniowe Henryka II składały się wyłącznie z jazdy bądź z piechurów, którzy poruszali się konno, a walczyli pieszo, np. kuszników, bowiem majątek królewski pozwalał na wyposażenie wojsk w liczne konie. Za „,siłami szybkiego reagowania" podążały wolniejsze tabory z zaopatrzeniem i machinami. Kontyngenty brabanckiej jazdy zabierały niezbędny niewielki ekwipunek i zaopatrzenie na konie juczne, a normandzkie miasta zapewniały przesył niezbędnych środków. Te udogodnienia pozwoliły Henrykowi II na zrealizowanie ulubionej taktyki dążenia do rozbicia głównych nieprzyjacielskich sił w walnej bitwie, a dopiero potem, kiedy tyły operującej armii były bezpieczne, na neutralizowanie wrogich zamków. Nie znamy szczegółów dotyczących ustawienia formacji wojsk króla Anglii. Źródła jednoznacznie podają że pojawiały się naprzeciwko wrogów we wzorowym szyku bojowym i z zaskoczenia atakowały zdezorientowanych najeźdźców. Należy zwrócić uwagę na panikę, zarówno wojsk, jak i dowódców, takich jak Ludwik VII w obliczu konfrontacji z siłami pod dowództwem króla Anglii. W przeciwieństwie do Plantageneta kapetyński monarcha obawiał się walnych starć, wybierając raczej powolne obleganie twierdz i pustoszenie zajętych terenów. Liczył na łatwe zwycięstwa i nie lubił podejmować ryzyka. Natomiast angielski wódz pewny siebie wydawał rozkazy i przeprowadzał natarcia. Podczas oblężeń Henryk II 
okazywał się również zdolnym taktykiem, często zdobywając umocnienia szturmem i z zaskoczenia. Ponadto dużym atutem władcy było posiadanie licznych machin oblężniczych, które, jak pokazuje przykład kapitulacji Dol, świadczyły o przewadze nad wrogiem.

Obrona Normandii podczas Wielkiej Rewolty lat 1173-1174 ukazała zdolności strategiczne i taktyczne Henryka II Plantageneta, kierującego się nowatorskimi jak na owe czasy posunięciami oraz wykorzystującego głównie atuty zawodowych najemnych formacji zamiast feudalnych zaciągów, na których wciąż polegali jego antagoniści. Podobną taktykę i strategię, opierającą się na silnie umocnionych zamkach przygranicznych oraz mobilnych formacjach zastosował podczas walk w Normandii w latach 1195-1198 syn Henryka II - Ryszard Lwie Serce ${ }^{65}$, czego przykładem jest zwłaszcza nagły atak na wojska francuskie pod Verneuil i analogiczna do wydarzeń z 1173 r. ucieczka syna Ludwika VII - Filipa II Augusta spod murów tej wielokrotnie obleganej twierdzy. Nasuwa się zatem wniosek, że syn zawdzięczał znienawidzonemu ojcu więcej nauki sztuki wojennej, niż się wydaje.

\section{BIBLIOGRAFIA (REFERENCES)}

\section{Źródła}

Acta of Henry II and Richard I, eds. J.C. Holt, R. Mortimer, „List \& Index Society Special Series", t. 21, Richmond 1986.

Acta of Henry II and Richard I, part 2, ed. N. Vincent, „List \& Index Society Special Series”, t. 27, Richmond 1996.

Fantosme J., Chronicle of the War between the English and the Scots in 1173 and 1174, tłum. wstęp i red. F. Michel, Londyn-Edynburg 1840.

Gervase of Canterbury, The Historical Works of Gervase of Canterbury, t. 1-2, ed. W. Stubbs, London-Oxford-Cambridge-Edinburgh-Dublin 1879-1880.

Gesta Regis Henrici, w: The Chronicle of Henry II and Richard I AD 1169-1192, ed. W. Stubbs, London 1867.

Ralph de Diceto, Ymagines Historianum, w: The Historical Works of Master Ralph of Diceto, Dean of London, ed. W. Stubbs, London 1876.

Robert de Torigny, The Chronicle of Robert of Torigny, w: Chronicles of Reigns of Stephen. Henry II and Richard I, t. 2, ed. R. Howlett, 13 Rolls Series, London-Oxford-CambridgeEdinburgh-Dublin 1884-1889.

Roger of Hoveden, The Annals of Roger de Hoveden, 2 vols, tłum. H.T. Riley, London-Bohn 1853.

The Chronicle of the Reigns of Stephen, Henry II, and Richard I, by Gervase, the Monk of Canterbury, ed. W. Stubbs, 2 vols. (RS 73, London 1879-1880).

William of Newburgh, Historia Rerum Anglicarum, ed. R. Howlett, w: Chronicles and Memorials of the Reigns of Stephen, Henry II, and Richard, t. 1 i 2, London 1888-1890.

William of Newburgh, The History of England (c. 1196), w: English Historical Documents online, t. 2: 1042-1189, eds. D.C. Douglas, G.W. Greenaway, Routledge 2015.

65 Por. J. Gillingham, Ryszard Lwie Serce, op. cit., s. 373-386. 
William of Newburgh, The History of English Affairs, w: The Church Historians of England, t. 4, cz. 2, tłum. J. Stevenson, London 1861 (słownictwo poprawione w 1999 r. przez S. McLetchie).

\section{Opracowania}

Aurell M., L'Empire des Plantagenêt 1154-1224, Paris 2003.

Aurell M., Révolte nobiliaire et lutte dynastique dans l'Empire angevin (1154-1224), w: Anglo-Norman Studies, t. 24: Proceedings of the Battle Conference 2000, ed. G. Gillingham, Woodbridge 2001.

Bachrach B.S., Henry II and the Angevin Tradition of Family Hostility, "Albion” 1984, 16.

Barlett R., England under the Norman and Angevin Kings 1075-1225, Oxford 2000.

Bates D., The Rise and Fall of Normandy, c. 911-1204, w: England and Normandy in the Middle Ages, eds. D. Bates, A. Curry, London 1994, s. 19-36.

Beeler J., Warfare in England 1066-1189, New York 1966.

Boussard J., Les mercenaires au XII siècle: Henri II Plantagenêt et les origins de l'armée de métier, w: Bibliothèque de l'école des Chartes, t. 106 (Paris 1945-1946).

Dunbabin J., France in the Making, 843-1180, Oxford 2000.

Gillingham J., Ryszard Lwie Serce, tłum. N. Rataj, M. Józefowicz, Kraków 2016.

Gillingham J., The Angevin Empire, second edition, London-New York 2001.

Henry II. New Interpretations, eds. Ch. Harper-Bill, N. Vincent, Woodbrigde 2007.

Hoolister C.W., The Military Organization of Norman England, Oxford 1965.

Hosler J.D., Henry II. A Medieval Soldier at War, Leiden-Boston 2007.

Hosler J.D., Revisiting Merceneries under Henry Fitz Empress 1167-1188, w: Merceneries and Paid Men. The Mercenary Identity in the Middle Ages, Proceedings of a Conference held at University of Wales, Swansea, $7^{\text {th }}-9^{\text {th }}$ July 2005, ed. J. France, Leiden-Boston 2008.

Hosler J.D., The Warfare of Henry II, 1149-1189, praca doktorska, Ann Arbor 2005.

Isaac S., Cowardice and Fear Management: The 1173-74 Conflict as a Case Study, w: The Journal of Medieval Military History, t. 4, eds. C.J. Rogers, K. DeVries, J. France, Woodbridge 2006.

Jones T.M., The Generation Gap of 1173-74: The War between the Two Henrys, "Albion” 1973, 5, s. 24-40.

Jones T.M., War of the Generations: The Revolt of 1173-4, Ann Arbor 1980.

La Normandie entre Plantagenêts et Capétiens, eds. A.M. Flambard Héricher, V. Gazeau, Caen 2007.

McLynn F., Lionheart and Lackland. King Richard, King John and the Wars of Conquest, London 2006.

Norgate K., England under The Angevin Kings, t. 1 i 2, London 1887.

Power D., The Norman Frontier in the Twelth and Early Thirteenth Centuries, Cambridge 2008.

Power D., What Did the Frontier of Angevin Normandy Comprise?, w: Anglo-Norman Studies, Proceedings of the Battle Conference 1994, t. 17, Woodbridge 1995, s. 181-202.

Powicke M., Utrata Normandii 1189-1204. Studia nad Historia Imperium Andegaweńskiego, tłum. I. Smoczyk-Jackowiak, Oświęcim 2016.

Prestwich J.O., The Place of War in English History, 1066-1214, Woodbridge 2004.

Schlight J., Medieval Merceneries: Their Importance to Eleventh and Twelfth Century English Kings, praca doktorska, Ann Arbor 1965.

Strickland M.J., Henry the Young King, 1155-1183, New Heaven-London 2016. 


\section{ABSTRACT}

In 1173, the King of England Henry II Plantagenet was confronted with a strategically difficult task, as a result of dangerous military situation. He was forced to fight on several fronts against expected hostile actions in the Northern and the Middle England, as well as in Normandy, because his sons: Henry, known as the "Young King", Richard, and Geoffrey had rebelled against him as the Sovereign. They were supported by a strong coalition led by the King Louis VII of France. Their primary objective was to capture the Duchy of Normandy with its heart - Rouen. For this reason, the city was the main target for attacks directed from the South, North-East and West. Henry II treated the defence of that strategically and economically important region as the pivotal task during the war.

The purpose of the article is to analyse Henry II Plantagenet's innovative strategy and tactics during the defence of Normandy in 1173-1174. The other important task is to point the "Old King's" warfare skills that permitted him to repulse not only the individual attacks of his enemies, but also enabled him to win the war.

Key words: strategy and tactics, Plantagenets, Angevin Empire, The Great Revolt 1173-1174, Normandy, Henry II of England, medieval warfare

\section{NOTA O AUTORZE}

Wojciech Lorek - doktorant w Zakładzie Historii Średniowiecza Instytutu Historii Uniwersytetu im. Adama Mickiewicza w Poznaniu, pracownik Wielkopolskiego Muzeum Wojskowego, Oddziału Muzeum Narodowego w Poznaniu. Zajmuje się historią Anglii i Francji w XII i XIII w., krucjatami oraz historią wojskowości. Autor książki Krucjaty Ludwika IX Świętego 1248-1270 (Oświęcim 2015), a także licznych artykułów naukowych i popularnonaukowych, popularyzator historii. E-mail: crusader1@onet.eu 